Ethnic Entrepreneurs 



\section{Ethnic Entrepreneurs}

Identity and Development Politics in Latin America

Monica C. DeHart 
For Nayana and Ella

Stanford University Press

Stanford, California

(C)2010 by the Board of Trustees of the Leland Stanford Junior University. All rights reserved.

No part of this book may be reproduced or transmitted in any form or by any means, electronic or mechanical, including photocopying and recording, or in any information storage or retrieval system without the prior written permission of Stanford University Press.

Printed in the United States of America on acid-free, archival-quality paper

Library of Congress Cataloging-in-Publication Data

DeHart, Monica C. (Monica Christine)

Ethnic entrepreneurs : identity and development politics in Latin America / Monica C. DeHart. p. $\mathrm{cm}$.

Includes bibliographical references and index.

ISBN 978-0-8047-6933-4 (cloth : alk. paper)—ISBN 978-0-8047-6934-1 (pbk. : alk. paper)

1. Ethnicity—Latin America. 2. Economic development—Social aspects—Latin America.

3. Entrepreneurship—Social aspects—Latin America. I. Title.

F1419.A1D43 2010

$305.80098-\mathrm{dc} 22$

2009021944

Typeset by Bruce Lundquist in 10/14 Minion 